\title{
Some Notes on the Vértesszöllös Occipital ${ }^{1}$
}

MILFORD H. WOLPOFF

Department of Anthropology, University of Michigan, Ann Arbor, Michigan 48109

\author{
KEY WORDS Vértesszöllös · Homo erectus · Occipital · Extra- \\ sutural bones
}

\begin{abstract}
An examination of the Vertesszöllös occipital bone indicates the need for taking its condition and preservation as well as certain aspects of its morphology into account prior to a metric assessment of its features. This analysis confirms the presence of extrasutural bones on the lambdoidal suture as well as some distortion in the sagittal curvature of this region. The advisability of using the endocranial sutures as well as other data for defining lambda in cases such as this is discussed, and a procedure for determining the position of opisthion is indicated. A metric and morphological analysis is used to support the claim that the specimen can be considered a large late representative of Homo erectus in Europe.
\end{abstract}

The occiput from Vértesszöllös is the only hominid cranial fragment known from the European Mindel at the present time. Because there is only a single specimen, the desire to obtain as much information from it as possible must be balanced against the fact that it cannot represent the range of the population from which it was drawn and may or may not approximate the mean. The potential importance of the specimen lies in the knowledge it provides concerning evolutionary changes at the very end of the Homo erectus lineage or the very beginning of the Homo sapiens one, depending on how it is interpreted taxonomically; other important facets include the question of whether European hominids are geographically distinct from their contemporaries and whether there is evidence for multiple hominid lineages in Europe during the Mindel. It is possible that the potential importance of the specimen has led to its overinterpretation. However, another factor underlying the continuing discussions regarding the specimen results from the damaged and incomplete condition of the bone. I had the opportunity to examine this specimen during the summer of 1976. The purpose of this report is to ascertain the influence of damage and distortion on the interpretation of the specimen, to discuss the problems involved in delineating some of the important landmarks, and to compare it with occiputs from other
Riss and pre-Riss European hominids with the intent of determining its relationship to them.

\section{SOME PROBLEMS IN PRESERVATION}

While the occiput recovered from the Hungarian site of Vértesszöllös is in surprisingly good condition, given its age (Kretzoi and Vértes, '65) and the lack of substantial internal mineralization, some elements of distortion combined with the preserved morphology underlie the continuing discussions concerning its phylogenetic position (Thoma, ' 66 , ' 69 , '72; Howells, '66; Wolpoff, '71). Metric comparisons have been hampered by the absence of opisthion and questions concerning the position of lambda, while morphological evaluation must contend with the absence of virtually all of the outer bone table in the region of the nuchal torus and elsewhere, as well as with what appear to be numerous breaks and angled joins in the superior occipital plane.

The main distortions in the bone occur towards the top of the occipital place (fig. 1). Here, reconstruction (or its absence) has resulted in an unusual angulation at the most superior aspect of the bone, sharply setting the curvature off from the relatively smoothly curving occipital plane. This acts to make the

\footnotetext{
${ }^{1}$ This research was supported by NSF grant BNS 75-21756 and grant from the National Academy of Sciences Eastern European Program.
} 


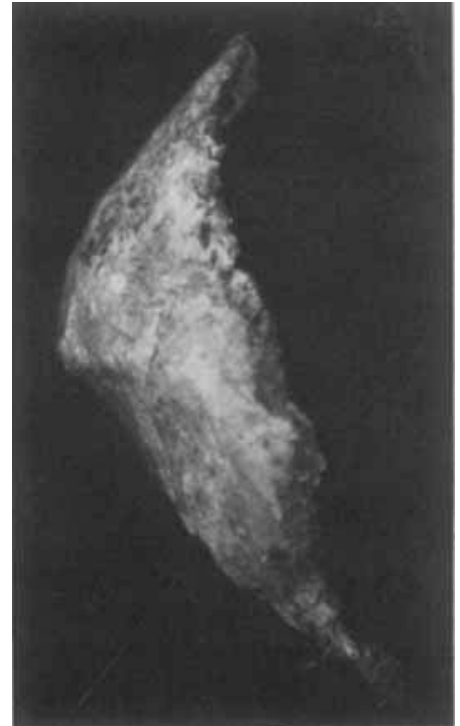

Fig. 1 Lateral view of the occiput, showing the deep sulcus below the nuchal torus, and the bulging effect above it.

occipital curvature appear too high. Inferior and posterior to this, the occipital plane swells convexly and gives the superficial appearance of a "Neandertal-like" bun. The top of this swelling is some $13 \mathrm{~mm}$ below lambda (see discussion below) and $36.8 \mathrm{~mm}$ above inion. However, unlike the condition in these later European hominids there is no corresponding fossa internally. Instead, the internal surface is smoothly curved so that the apparent bulge is the result of thickened bone.

No sulcus spearates this convex region from the nuchal torus below, although a deep sulcus lies inferior to the torus. However, virtually no outer bone table remains on the torus so that its true size is easily underestimated. Observed where the full bone surface remains (as in the position of inion), the torus is projecting and is rather thick (fig. 2). Its position is high above the internal inion (table 2).

\section{Opisthion}

While prior metric analyses of the specimen (Thoma, '66, '69, '72; Wolpoff, '71) utilized measures of both nuchal and occipital planes, procedures regarding the definitions of the positions for both lambda and opisthion must be explicitly stated since there are problems regarding both measuring points. In the case of opisthion, the problem is quite simply that the bone is broken away posterior to the foramen magnum border, and in fact not far anterior to the position of internal inion in some positions.

The position of opisthion can be estimated from other landmarks. The relatively high position of the external inion makes it difficult

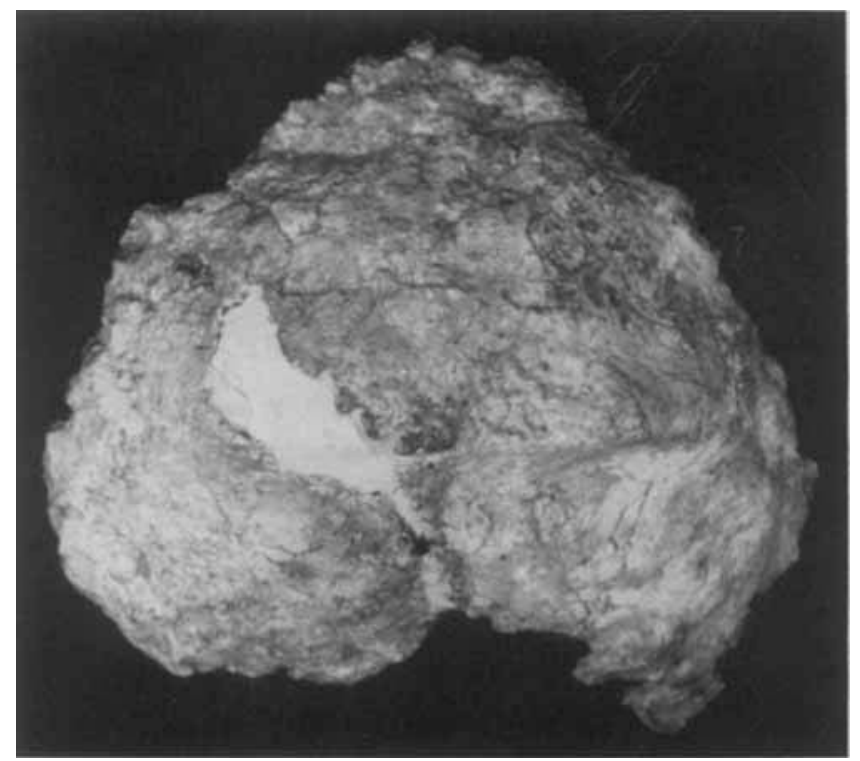

Fig. 2 Posterior view of the occiput. 
to use in estimating opisthion. For instance, if a Swanscombe model is used, emphasizing the more derived features of the specimen, opisthion would be placed $51 \mathrm{~mm}$ from inion. However, this would position it only $25 \mathrm{~mm}$ from the internal occipital protuberance (endinion), in contrast to the corresponding Swanscombe value of $30.6 \mathrm{~mm}$.

Other features can more accurately be used to position the posterior border of the foramen magnum. A notch visible on the broken edge of the inferior right surface seems to represent the posterior portion of the condylar fossa border; a smaller portion of the posterior border appears in the symmetric position on the left (fig. 3). Medial and anterior to the right notch border a small ridge appears to mark the lateral base of the condyle on the jugular process. Both of these features lie anterior to opisthion, and thus help define its position.

Comparison with the internal morphology of Swanscombe (the only cast available) reveals a virtually identical position for the features described above, as well as an equivalent position for the divergence of the lines laterally bounding the occipital sinus as measured from endinion. Use of the Swanscombe occiput as a model seems justified by these comparisons, and the position of opisthion was placed some $30.5 \mathrm{~mm}$ below endinion. Although this estimate provides a minimum inion-opisthion dimension (table 1), the nuchal plane of Vértesszöllös appears to have been very long. The $57 \mathrm{~mm}$ value thus determined is virtually the same as the $56 \mathrm{~mm}$ dimension reported by Thoma ('69: p. 234).

\section{$L a m b d a$}

There are also some difficulties concerning the true position of lambda. Contra Thoma ('72) lambda is not at the most superior and anterior point on the midline of the bone as preserved. As I previously stated on the basis of a cast examined at the Harvard Peabody Museum, extrasutural bones on the anterior border of the occipital confuse the definition of lambda. Thoma regards these as "small fractures of the tabula externa" (p. 464). My examination of the original specimen suggests that both statements are probably correct; there is considerable breakage in the area and extrasutural bones are present. Several different factors lead me to conclude that more than breakage characterizes this area (fig. 4). (1)

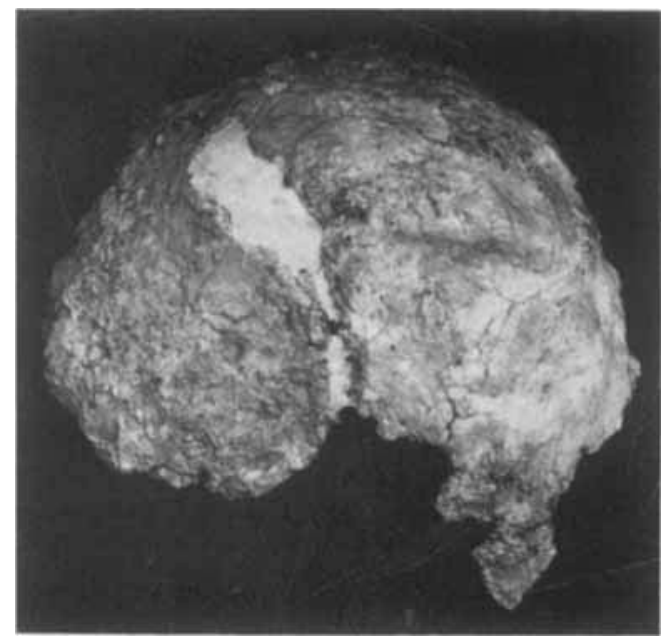

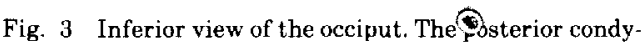
lar fossa border is on the superior edge of the large broken notch on the lower right.

Many of the fractures, if they are such, extend through to the internal bone surface and could just as easily define extrasutural bones. (2) The termination of the cerebral fossa is clearly observable, marking the superior border of the occiput. However this termination lies below the superior border of the preserved internal surface. (3) The most superior extension of the sagittal sulcus falls some $21.5 \mathrm{~mm}$ short of the most superior anterior point on the midline (Thoma's lambda) although it normally extends to lambda. (4) In the region superior and anterior to the termination of the sulcus the unusual angulation of the occipital plane occurs, described above as a consequence of breaks.

Yet, if the region anterior and superior to the border of the sagittal sulcus is not part of the occiput, the absence of sagittal suture indicates that it is also not part of the parietal. Instead, the region consists of at least two definable extrasutural bones. The condition is similar to the large extrasutural bone found in the pre-Riss cranium from Petralona (fig. 5), although in this case the extrasutural bone involves only the occiput. These bones should not be used in metric or morphologic descriptions of either occipital or parietal; including them as part of the occipital leads to the unusual length of the occipital plane reported by Thoma ('69). Thoma's occipital length is not homologous with the dimension as normally defined since it includes bone surface 
TABLE 1

Comparison of dimensions on the sagittal plane for Vertesszöllös and Swanscombe, Petralona, and a cast of La Chaise 2

\begin{tabular}{|c|c|c|c|c|c|c|c|c|}
\hline & \multirow{2}{*}{ La Chaise } & \multirow[b]{2}{*}{ Petralona } & \multirow[b]{2}{*}{ Swanscombe } & \multicolumn{5}{|c|}{ Vérteszöllös } \\
\hline & & & & a & $\mathrm{b}$ & $\mathrm{c}$ & d & e \\
\hline \multicolumn{9}{|l|}{ Lambda-opisthion } \\
\hline Chord & 84.7 & 92.9 & 93.5 & 91.6 & 107.3 & 99.0 & 100.0 & 102.0 \\
\hline Arc & 108.0 & 130.0 & 117.0 & 111.0 & 132.0 & & & \\
\hline Index & 127.5 & 139.9 & 125.1 & 121.2 & 123.0 & & & \\
\hline \multicolumn{9}{|l|}{$\begin{array}{l}\text { Occipital plane } \\
\quad \text { (inion-lambda) }\end{array}$} \\
\hline Chord & 49.5 & 63.6 & 58.0 & 49.8 & 71.3 & & & 73.0 \\
\hline Arc & 55.0 & 68.0 & 63.0 & 53.0 & 74.0 & & & 79.0 \\
\hline Index & 111.1 & 107.9 & 108.6 & 107.1 & 103.8 & & & 108.2 \\
\hline \multicolumn{9}{|l|}{$\begin{array}{l}\text { Nuchal plane } \\
\text { (opisthion-inion) }\end{array}$} \\
\hline Chord & 51.0 & 60.6 & 51.0 & 57.0 & 57.0 & & 53.0 & 56.0 \\
\hline Arc & 53.0 & 62.0 & 54.0 & 58.0 & 58.0 & & & \\
\hline Index & 103.0 & 102.3 & 105.9 & 101.8 & 101.8 & & & \\
\hline \multicolumn{9}{|l|}{$\begin{array}{l}\text { Occipital-nuchal } \\
\text { index }\end{array}$} \\
\hline Chord & 97.1 & 105.0 & 113.7 & 87.4 & 125.1 & & & 130.4 \\
\hline Arc & 103.8 & 109.7 & 116.7 & 91.4 & 127.6 & & & \\
\hline Inion angle & $114.9^{\circ}$ & $96.8^{\circ}$ & $118.0^{\circ}$ & $118.0^{\circ}$ & $113.0^{\circ}$ & & & $103.7^{\circ}$ \\
\hline Lambda angle & $33.1^{\circ}$ & $40.4^{\circ}$ & $28.8^{\circ}$ & $33.3^{\circ}$ & $29.3^{\circ}$ & & & $32.2^{\circ}$ \\
\hline Opisthion angle & $32.0^{\circ}$ & $42.8^{\circ}$ & $33.2^{\circ}$ & $28.7^{\circ}$ & $37.7^{\circ}$ & & & $44.0^{\circ}$ \\
\hline
\end{tabular}

All dimensions are in millimeters and with the exception of La Chaise were taken on the original specimens. The three angles were calculated from the dimensions of the sides of a triangle defined by the occipital plane, nuchal plane, and lambda-opisthion chord. Under the Vertesszollös heading are the following:

a, position of lambda and opisthion as discussed in text, determined on the original specimen by Wolpoff

b, position of opiathion ag above, lambda defined as the point used by Thoma (the most anterior preserved point on the midline

c. taken by Wolpoti on a cast ("71)

d, measured by Tohias, reported in Thoma ('69)

e, measured by 'lhoma ('69).

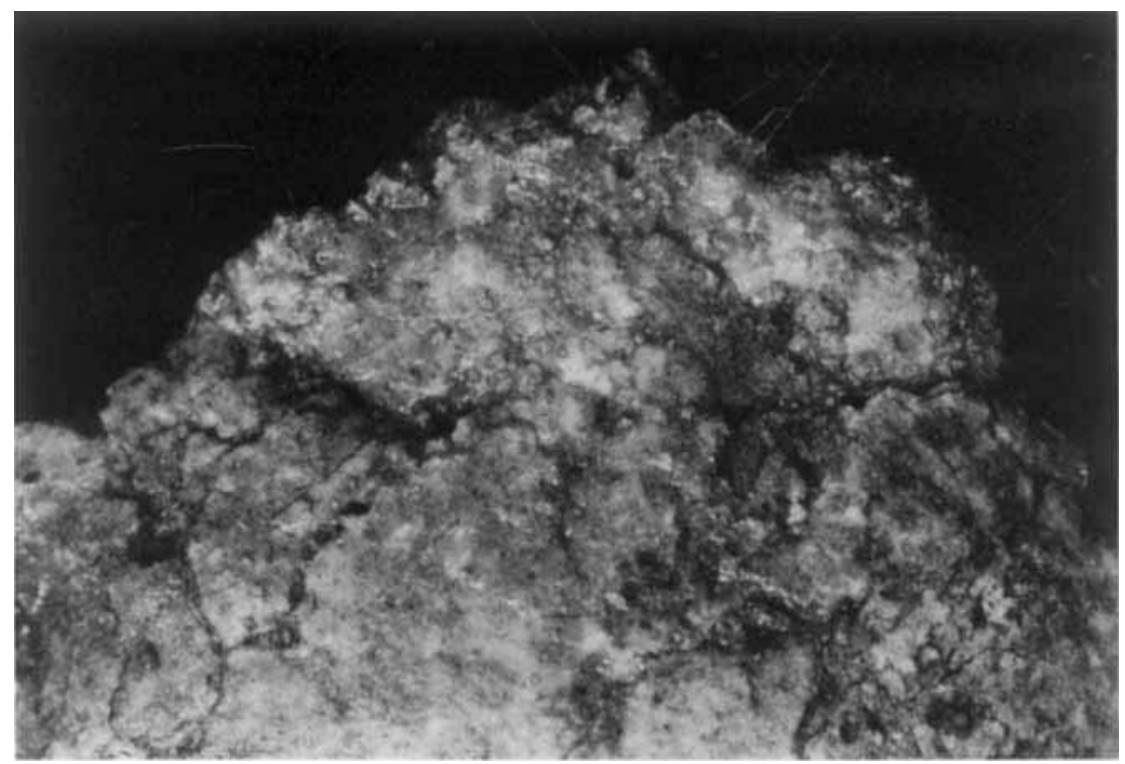

Fig. 4 View of the region surrounding the most superior aspect of the lambdoidal suture. This area seems to be characterized by both breaks and the presence of extra sutural bones. 


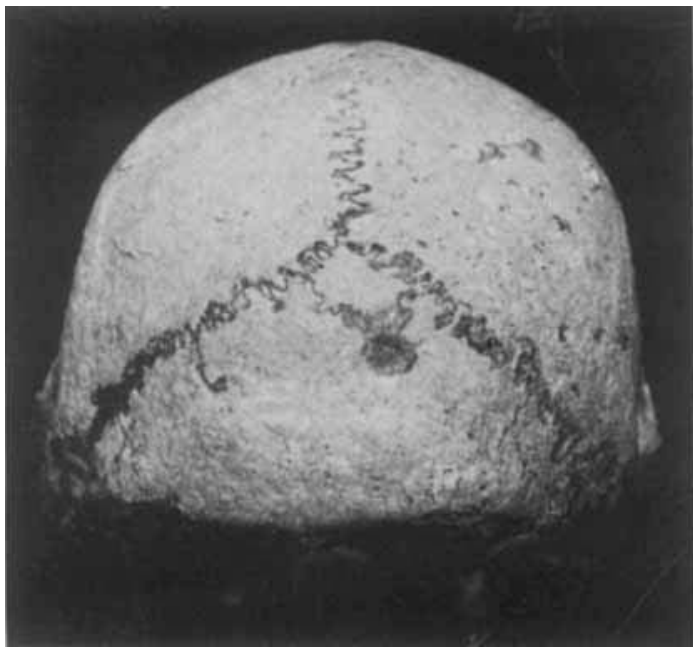

Fig. 5 Posterior view of the Petralona cranium. Note the large extrasutural bone just below lambda.

covering more than the occipital lobes of the brain.

The homologous measurement can be defined by treating the extrasutural bones as neither part of the occiput nor the parietal, and defining lambda on the basis of the internal morphology as in MLD 2 (Wolpoff, '74). This would place lambda internally some $\mathbf{5 7 . 5}$ $\mathrm{mm}$ above the endinion position, and externally $49.8 \mathrm{~mm}$ above inion (table 2 ). The resulting height of the left cerebral fossa is $56 \mathrm{~mm}$ while on the right it is $47 \mathrm{~mm}$ from the transverse sinus to the internal position of lambda. The asymmetry is exactly the opposite of Swanscombe, where the right cerebral fossa is the larger.

\section{AFFINITIES}

Evaluation of the metrics (tables 1,2) indicates that Vértesszöllös is a large specimen. Generally, its dimensions exceed those of Homo erectus occiputs in the total height of the bone, as indicated by the lambda-opisthion chord as reconstructed by the author. Since both nuchal and occipital plane lengths fall well within the erectus range, the greater height of the bone is the result of a higher angle measured at inion; the value of $118^{\circ}$ reported here exceeds the $103^{\circ}$ value given by Thoma ('69) and both values may be incorrect because of the presence of sagittal distortion in this region discussed above.

In spite of its size, the occiput shows a series of affinities to the Homo erectus sample, matched by differences from the other fairly early occiputs from Europe; I interpret these to suggest that it probably should be included in the former taxon. Moreover, no features indicate that it represents a population ancestral to only some of the later European hominids while not to others (i.e., a pre-Riss lineage divergence of European hominids, or the "Presapiens Hypothesis"). This interpretation is now also agreeable to Thoma ('76).

My reasons for considering the Vértesszöllös occiput as a late representative of Homo erectus include the many detailed resemblances discussed by both Thoma ('66, '69) and myself ('71), and the position of the specimen with respect to trends in the evolution of the mid-Pleistocene occipital. Apart from some specific morphological characters, the main aspects that characterize the occiputs of the earliest members of Homo sapiens result from selection reducing the length of the nuchal plane (while generally increasing its breadth) and increasing the length of the occipital plane. The index formed by these two lengths changes markedly, passing from a value of about 70 in Homo erectus (i.e., the occipital plane is $70 \%$ the length of the nuchal plane) to 113 in six Solo crania and considerably higher values in the Würm Neandertals. Values for European hominids from the mid-Pleistocene are all above the erectus range (maximum index is 94) except for Vértesszöllös (table 1) which falls close to the Choukoutien mean of 83.

Other characteristics which progressively change with the appearance and subsequent evolution of Homo sapiens include the approach of internal and external inion as the nuchal plane decreases in length (the Vértesszöllös inion is far above endinion); the loss of the sulcus inferior to the nuchal torus (Vértesszöllös retains the sulcus); the "filling out" of the occipital plane resulting in a high arcchord index (the Vértesszöllös index is like both Homo erectus and the earlier European hominids); thinning of the occipital in the regions of asterion and inion (the Vértesszöllös values for bone thickness are close to the erectus mean); and the more open occipital angle measured at inion (here alone is Vértesszöllös more like the later hominids and outside of the known Homo erectus range). In some respects, the Petralona occiput resembles Vértesszöllös. There is a similar ap- 
TABLE 2

Comparison of Vertesszöllos dimensions (mm) with the specimens used in table 1

\begin{tabular}{|c|c|c|c|c|c|}
\hline & \multirow[b]{2}{*}{ La Chaise } & \multirow[b]{2}{*}{ Petralona } & \multirow[b]{2}{*}{ Swanscombe } & \multicolumn{2}{|c|}{ Vértesszölläs } \\
\hline & & & & a & $\mathrm{b}$ \\
\hline Biasterionic breadth & 109.0 & 119.0 & 121.8 & 128.3 & \\
\hline Nuchal plane breadth & 105.5 & 106.5 & 84.5 & 108.0 & \\
\hline Biasterionic arc & & 155.0 & 160.0 & 150.0 & \\
\hline Lambda-asterion & & & & & \\
\hline $\begin{array}{ll}\text { Chord } & \mathrm{L} \\
\mathbf{R}\end{array}$ & & $\begin{array}{l}87.3 \\
80.0\end{array}$ & 91.6 & $\begin{array}{l}90.3 \\
85.8\end{array}$ & $\begin{array}{r}100.5 \\
96.0\end{array}$ \\
\hline Are $\quad \mathrm{L}$ & & 97.0 & 104.0 & 101.0 & 115.0 \\
\hline $\begin{array}{cc} & \mathrm{R} \\
\text { Index } & \mathrm{L} \\
& \mathrm{R}\end{array}$ & 101.0 & 90.0 & & 97.0 & 111.0 \\
\hline Inion-internal protuberance & 11.0 & & 15.8 & 27.8 & \\
\hline $\begin{array}{l}\text { Maximum thickness at } \\
\text { Asterion } \\
\text { Lambda } \\
\text { Inion } \\
\text { Internal protuberance }\end{array}$ & $\begin{array}{l}11.3 \\
11.6 \\
14.0 \\
15.0\end{array}$ & & $\begin{array}{r}10.4 \\
9.0 \\
14.5\end{array}$ & $\begin{array}{l}14.3 \\
10.0 \\
16.0 \\
10.0\end{array}$ & \\
\hline Minimum thickness & 3.5 & & 6.0 & 3.0 & \\
\hline
\end{tabular}

"a" and "b" are as defined in table 1.

parent bun-like configuration to the occipital plane and a sulcus below it, although not as deep. The occipital plane exceeds the nuchal plane in length, and the lambda-opisthion chord is greater (and the arc much greater) in spite of the lower occipital angle. A greater contrast is provided by the Bilzingsleben occiput (Mania, '75) which is smaller and less strongly angled (about $113^{\circ}$ ), with little curvature in the occipital sagittal plane. Steinheim has a longer and more rounded occipital plane in its present condition (Weinert, '36). How an eventual reconstruction will effect this is unknown, and in any event the specimen may be younger than normally assumed.

\section{CRANIAL CAPACITY}

Finally, the capacity of the specimen has been used in assessing its phylogenetic position, although a direct determination is impossible from the occiput alone. Estimation of the Vértesszöllös cranial capacity has been attempted on the basis of linear regressions from the lambda-opisthion chord (Thoma, '69; Wolpoff, '71). However, for a regression based on the lambda-opisthion chord to be used in calculating cranial capacity, two different problems must be settled. First which specimens should provide the basis for defining the regression (Olivier and Tissier, '75)? A regression based on Neandertals gives quite different results from one based on Homo erectus (Wolpoff, '71). Thus, using capacity to argue for a particular taxonomic position is bound to be circular, since one must make a taxonomic decision in order to determine the capacity. Second, which of the different lambda-opisthion estimates should be used; values have been provided by Thoma, Tobias, and myself in various publications as well as this one.

In table 3, all of the lambda-opisthion estimates are used to calculate capacity in a series of regressions based on the seven Homo erectus specimens with lambda-opisthion dimensions that can be determined without reconstruction. Since Thoma ('72) has suggested that an exponential curve instead of a line be used to relate the chord to capacity, least square formulae are determined for a line, a second degree polynomial, a power curve, and an exponential curve. As it turns out, none of these have dramatically different percent errors when applied to the samples from which they were derived, and the estimates of the Vértesszöllös capacity likewise are not particularly sensitive to which model is used.

The Vértesszöllös estimate is much more sensitive to which lambda-opisthion chord estimate is used; a $10 \mathrm{~mm}$ difference in the chord can effect the capacity estimate between $224 \mathrm{cc}$ in the linear regression and 310 $\mathrm{cc}$ in the exponential regression. While I would support the capacity estimate based on the lambda-opisthion chord determined between the points as defined here, the different 
TABLE 3

Derivation of four curves for estimating cranial capacity from the lambda-opisthion chord in Homo erectus specimens with a known lambda-opisthion dimension

\begin{tabular}{|c|c|c|c|c|c|c|}
\hline & $\begin{array}{l}\text { Lambda } \\
\text { opisthion } \\
\text { chord }\end{array}$ & $\begin{array}{c}\text { Actual or } \\
\text { estimated } \\
\text { capacity }\end{array}$ & $\begin{array}{l}\mathrm{Y}=\mathrm{AX}+\mathrm{B} \\
\text { Linear } \\
\text { regression } \\
\text { capacity }\end{array}$ & $\begin{array}{l}=\mathrm{AX}^{2}+\mathrm{BX} \\
\text { Polynomial } \\
\text { regression } \\
\text { capacity }\end{array}$ & $\begin{array}{l}\mathrm{C}=\mathrm{AX} \\
\text { Power } \\
\text { curve } \\
\text { capacity }\end{array}$ & 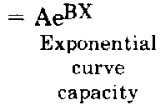 \\
\hline Sangiran 2 & 75 & 775 & 735 & 739 & 740 & 745 \\
\hline Sangiran 4 & 78 & 750 & 802 & 802 & 802 & 802 \\
\hline Sangiran 12 & 83 & 900 & 914 & 911 & 909 & 905 \\
\hline Peking 3 & 84 & 915 & 936 & 934 & 932 & 928 \\
\hline Peking 11 & 86 & 1,015 & 981 & 979 & 977 & 974 \\
\hline Peking 12 & 87 & 1,030 & 1,004 & 1,002 & 1,000 & 998 \\
\hline Percent Error ${ }^{1}$ & & & $3.3 \%$ & $3.2 \%$ & $3.3 \%$ & $3.2 \%$ \\
\hline Values A & & & 22.37 & 0.09 & 0.12 & 120.37 \\
\hline B & & & -942.82 & 8.05 & 2.03 & 0.02 \\
\hline \multirow{2}{*}{ Vértesszöllös estimate } & 100 & & 1,294 & 1,314 & 1,327 & 1,369 \\
\hline & 102 & & 1,339 & 1,365 & 1,381 & 1,437 \\
\hline
\end{tabular}

\footnotetext{
'Based on absolute difference.

All of the curves were determined through a least squares procedure. In turn, each curve is used to estimate the Vertesszöllös capacity given various determinations of the lambda-opisthion chord (see table 1), and the percent error of the curve as applied to calculating known erectus capacities is given.
}

capacity estimates should not mask the fact that if one treats the Vértesszöllös cranium as a late $H$. erectus, its capacity is in the uppermost portion of the erectus range whichever chord is correct.

\section{SUMMARY}

In sum, this occiput likely belonged to an individual with a cranial capacity near or perhaps even slightly above the known range for Homo erectus, although probably not much different from the capacity that can be estimated for the Ternifine juvenile parietal. Both the high occipital angle and the large capacity result from the value of the lambdaopisthion chord, and thus are not independent of each other. Moreover, the fact that both lambda and opisthion must be reconstructed or estimated in this specimen detracts from the value of estimates made on the basis of the chord. All other features of the specimen, both individually considered and in combination, are consistent with the interpretation that Vértesszöllös is a late and distinctively European Homo erectus which cannot be excluded from the ancestry of any later European hominid on the basis of morphology or metrics.

\section{ACKNOWLEDGMENTS}

I am very grateful to Doctor F. Fulep of the Magyar Nemzeti Museum for permission to examine and photograph the Vértesszöllös oc- cipital. I appreciate the help and cooperation provided by this institution. I also thank Doctor C. Stringer at the British Museum for permission to examine the La Chaise occipital cast and Swanscombe, and Doctor J. Melentis at the University of Thessaloniki for permis sion to study the Petralona cranium.

\section{LITERATURE CITED}

Howells, W. W. 1966 Homoerectus. Scien. Amer., 215(5) : 46-53.

Kretzoi, M., and L. Vértes 1965 Upper Biharian (intermindel) pebble-industry occupation site in Western Hungary. Current Anthrop., 6: 74-87.

Mania, D. 1975 Bilzingsleben (Thüringen): eine neue Altpaläolithische fundstelle mit Knochenresten des Homo erectus. Archäol. Korresp., 5: 263-272.

Olivier, G., and H. Tissier 1975 Determination of cranial capacity in fossil men. Am. J. Phys. Anthrop., 43: 353. 362.

Thoma, A. 1966 L'Occipital de l'homme mindelien de Vertesszöllös. L'Anthropologie, 70: 495-534.

1969 Biometrische Studie über das Occipitale von Vértesszöllös. Z. Morph. Anthrop., 60: 229-241.

465

1972 On Vértesszöllös man. Nature, 236: 464

1976 Le Peuplement anténéandertalien d'Europe dans le Contexte paléoanthropologique de l'Ancien Monde. In: Le Peuplement Anténéandertalien de l'Europe. A. Thoma, ed. CNRS, Paris, pp. 7-16.

Weinert, H. 1936 Der Urmenschenschädel von Steinheim. Z. Morph Anthrop., 35: 413-518.

Wolpoff, M. H. 1971 Vértesszöllös and the presapiens theory. Am. J. Phys. Anthrop., 35: 209-215.

1974 Sagittal cresting in the South African aus tralopithecines. Am. J. Phys. Anthrop., 40: 397.408 . 